\title{
Turning Poland Around - The Polish Economy 1990 - 2009
}

\author{
Gorm Jacobsen, University of Agder, Norway
}

\begin{abstract}
This article gives a description of the policy pursued by the Polish Government and the National Bank of Poland in the transformation of the Polish economy from a central planning economy to a market economy. There is special focus on the monetary economy, and most focus is laid on the first years of the transformation process.
\end{abstract}

The article also gives a presentation of the development of the main macroeconomic figures for the whole period since the introduction of the new economic system in Poland.

Keywords: Market Economy; Economic Development; Transition Economics; Economic History

\section{INTRODUCTION}

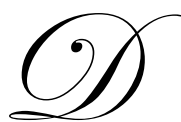

ue to low economic growth for decades and lack of economic and personal freedom, there were strong movements inside the Polish society struggling for a better life. The Polish economy like the economy of many other post-socialist countries was characterised by disequilibrium in almost every market. Most people had to use a great part of their time queuing up to buy what was necessary for their daily life. The struggle for freedom led by the Catholic Church and the labour union Solidarity, resulted in the collapse of the communist system. Solidarity became a political force and won the election to the Parliament in 1989, and the leader of Solidarity, Lech Walesa, became president in 1990.

Poland was one of the first post-socialist countries that changed from a central planning economy to a market economy. The new economic system was introduced on January 1, 1990.

Poland became full member of OECD in 1997, of NATO in 1999, and joined the EU on May 1, 2004.

This paper is a description of the policy that was pursued by the Government and the National Bank of Poland to improve the economic situation and to catch up with the Western countries.

\section{THE FIRST DECADE}

\subsection{The year 1990}

The new economic programme was launched at the beginning of 1990. Poland was the first post-socialist country to adopt such a radical policy. Unfortunately, the times were particularly difficult.

Hyperinflation at the end of 1989 and deep economic disequilibrium necessitated quick and radical steps. These steps were included in the economic policy package, which was agreed with international financial institutions; the International Monetary Fund and the World Bank. The key goals of the economic programme were:

\footnotetext{
- the slowdown of inflation

- the eradication of shortages

- the restoration of a proper role of the national currency to the condition of a market economy

- $\quad$ the beginning of the process of structural and ownership transformation suitable for the rise of economic efficiency
} 
The National Bank of Poland (NBP) and the Ministry of Finance participated in the realization of this program. This was particularly true in the following areas: control of money supply, interest rate and exchange rate policy.

This policy broke with the traditional doctrine in two ways. Firstly, the assumption that money should be passively created was rejected. Secondly, the budget deficit ceased to be automatically financed by bank credit.

From the monetary point of view, 1990 can be divided into three phases:

Phase one - from January to March, saw a sharp fall in domestic demand. This fall was a result of the devaluation of the zloty, the rise of interest rate and the abolition of subsidies. During this period a 50 per cent decrease of the money stock in real terms took place. This led, already after the first quarter of the year, to the appearance of excess supply and the development, for the first time in 45 years, of a buyer's market. A much deeper than assumed recession was, however, a negative effect of the economic programme.

Phase two - from April to September, was characterized by a slow rise of consumer demand. A substantial increase in the real money supply took place. This contributed to some rise of economic activity, particularly in the private sector.

Phase three - from October to December, as a result of the inflationary pressure, steps were taken aimed at reducing its rate. The rise of inflation was due both to external factors - the increase of the oil prices on world markets - and to internal factors, resulting from earlier loosening of income and monetary policies.

These signals inclined the NBP to tighten the monetary policy by available tools; interest rates and reserve requirements. Concurrently, in the second half of the year, new monetary policy tools were introduced, among others the NBP's bonds, credit guarantees, and collateral credit mechanism.

This year a rise of the role of domestic currency in economic transaction took place. Under the conditions of a stable exchange rate of the zloty to the American dollar, domestic currency became a basic medium of exchange and store of value. The large scale of foreign currencies in Polish economy - so-called "dollarization" of the economy - that developed in previous years was clearly reduced.

One of the most important achievements of last year's monetary policy was the maintenance of a uniform exchange rate in relation to USD at an unchanged level during the entire year (9500zl/USD). The stable exchange rate was an "anchor" of the economic programme, which held back inflation, stabilized the exchange processes with the external world, and strengthened the value of the domestic currency.

Simultaneously to the realization of the economic programme, NBP continued to work with the development and modernization of the banking system. In 1990 indispensable regulations concerning the creation of new banks, including banks with private and foreign capital, were brought into effect. A total of 49 banks were granted licenses, including 30 banks with a majority share of private capital. These licences were also granted to banks with foreign capital.

\section{Monetary policy}

\section{Central bank instruments}

The transformation of the banking sector and the establishment of a two-tier banking system in 1989 was a condition indispensable for a transition to the application by the central bank of monetary policy instruments characteristic of market economy. The changes consisted in a transition from administrative methods - detailed limitation of credit activities and directive formation to the principles of granting credits - to influencing the volume of money with economic instruments such as interest rate, obligatory reserves, exchange rate and operation on the money market. In 1990 changes in obligatory reserves were made depending on the monetary situation on the market and were aimed at decreasing the high liquidity in the banking system and making the system of cash supply more efficient. 
In order to support the development of the private sector NBP commenced on August 1, 1990 to give deposit-credit bank guarantees for credits destined for undertaking and development of economic activity in the private sector. The analysis of the guarantee applications allows to say that the credits to be covered by them were mostly destined for:

- $\quad$ commercial (wholesale or retail) activity; for instance for the purchase of goods, frequently abroad, erection of new places of sale and development or modernization of the already existing ones, purchase of transport means for commercial purposes, shop equipment

- $\quad$ service activity; e.g. hotels, dentists surgeries and tailor's shops

- $\quad$ erection, development or modernization of small businesses; e.g. bakery, confectionery and gastronomic units

- $\quad$ construction, extension or modernization of farm buildings

- $\quad$ purchase of shops, chemist's and sometimes privatization of smaller plants

At the end of July 1990 the NBP commenced sales and purchases of NBP bills. This instrument is to regulate the volume of the liquid reserves of the banking system and stimulate the development of the money market. NBP bills are short terms securities which can be subject to free turnover.

The principal direction of the monetary policy was defined in the Act of the Seym (parliament) of Poland February 23, 1990. They oblige the NBP to cooperate in:

- $\quad$ limiting inflation

- $\quad$ restoring the overall monetary balance in the economy

- $\quad$ introducing the internal convertibility of the zloty

All the activities of the NBP as well as the instruments of the monetary policy are applied, subordinated to the implementation of these targets, and in particular:

- $\quad$ interest rate policy protecting deposits and time savings against the consequences of inflation and inducing rational utilization of credits

- elimination of preferential credits in their hitherto used form reducing of the scope and change of the principles of financing preferential interest

- $\quad$ rearrangement of the problem of indebtedness in virtue of fixed and understated interest rate credits granted in the past

- $\quad$ abandonment of the practice of automatically financing the budgetary deficit by the central bank

- $\quad$ maintenance of a fixed exchange rate

The main task of the NBP was also to shape the supply of the domestic currency, so as not to create excessive demand, on the one hand, and not to allow for overdue payments in financial settlements, on the other.

The interest rate policy was aimed at:

- $\quad$ balancing the demand for money with its supply

- $\quad$ protecting the real value of deposits, in particular time deposits

- limiting the demand for bank credits simultaneously influencing borrowers to utilize these credits more rationally

- $\quad$ increasing the attractiveness of zloty deposits in order to make them grow faster than foreign deposits

In order to protect the interests of bank customers the president of the NBP recommended that banks should adapt the following rules as regards their deposit-credit policy:

- to calculate interest on credits on quarterly periods

- to calculate on deposits every quarter irrespective of the period for which the deposit was deposited as well 
as to give depositors a possibility to choose between their capital with the interest or drawing it out in cash after a quarter

- to establish contractual relations with customers in accordance with rules determined in advance and regarding the way of fixing the interest rate if it is to change within the period covered by the agreement

In accordance with the policy of economic stabilization the exchange rate policy was one of the essential factors in shifting inflation. The price of zls 9500 for 1 USD was 46 per cent higher than the price of December 31 , 1989 which amounted to zls 6500 . The main task of the exchange rate policy was to maintain a fixed exchange rate of the USD set at zls 9500 which limited the rate of inflation, on the one hand, and stimulated the growth of export and increased the competitiveness of domestically produced goods in relation to imported goods, on the other.

\section{The National Bank of Poland's national and international activity}

The main tasks of the NBP as the central foreign exchange institution include:

- $\quad$ organization of turnover in foreign currencies in accordance with the regulation of Act on Foreign Exchange Law

- foreign exchange control

- $\quad$ issue of individual foreign exchange banks, including authorizations to make international settlements, to give and draw foreign credits and give and accept guarantees in foreign trade turnover

In 1990 individual foreign exchange permissions were issued by 51 local NBP branches. They issued in total 104863 positive ones, against 2683 in 1989. 70 per cent of the enormous number of foreign exchange permissions concerns the export of privately owned currencies in connection with tourist trips to post-communist countries. The fact that the NBP commenced to issue such permissions was caused by public pressures connected with the poor provision of banks with the currencies of the countries in question, the same applying to exchange offices.

The year 1990 witnessed a slight growth of interest in economic activity consisting in running exchange offices dealing with the sale and purchase of foreign currencies. At the end of 1990 there were 2431 exchange offices in the country as a whole.

\section{Cooperation with the International Monetary Fund}

In 1990 cooperation with the IMF was of a character different from the previous years. This resulted from the implementation by Poland of the Government Stabilization Programme in the form of an adjustment programme supported by a stand-by credit. The stand-by credit granted to Poland by the IMF Council of Executive Directors which amounted to SDR $451 \mathrm{mn}$, i.e. USD $575 \mathrm{mn}$ to be put at the disposal of the Polish party in four instalments. The utilization of each subsequent instalment being dependent on the positive estimation of the observance of credit conditions by the fund. In 1990 the Polish side utilized three instalments of the stand-up credit. The utilization of the credit amounted to SDR $357 \mathrm{mn}$ i.e. USD $479 \mathrm{mn}$. The costs connected with the credit born by the Polish party reached USD $25 \mathrm{mn}$.

\section{Cooperation with the World Bank}

In 1990 six credit agreements were signed for a total amount of USD $1078 \mathrm{mn}$ which was destined for:

- $\quad$ financing pro-export ventures aimed at restoring or increasing the export abilities of economic units in different branches, food-processing and purchase of imported fodder (USD 360mn)

- $\quad$ improving the organizational structures and purchase of and monitoring equipment for environmental production laboratories (USD 18mn)

- $\quad$ financing the preparation of a transport project covering the modernization of the PKP (Polish state railways) exploitation-technical base as well as the introduction of an automated system of planning road network works (USD 150mn) 
- $\quad$ increasing the supply of energy carriers and gas production as well as improving the management system in the Polish oil and gas mining industry (USD 250mn)

- $\quad$ supporting the implementation of the agreed programme of economic reforms. Resources from this loan which amounts to USD 300mn could be used for the import of some goods and payment for foreign services. In 1990 the first instalment of this loan (USD 100mn) was available

Cooperation with the International Bank of Economic Cooperation (IBEC)

The year 1990 was the last year of the functioning of the transfer rouble in settlements between the Council for Mutual Economic Assistance and simultaneously the year of preparations for a transition to free currency settlements.

In December the President of the NBP participated in the emergency meeting at the IBEC Council, and signed on behalf of the Polish government the Protocol on the change of the Agreement on Multilateral Settlements in Transferable Roubles and the establishment of the IBEC as well as the Statue of the bank.

\section{Cooperation with the Credit National}

Acting on behalf of the Polish government the NBP signed an agreement on a loan amounting to FRF $682 \mathrm{mn}$. FRF $184 \mathrm{mn}$ of this amount was destined for utilization in 1990-1991 to finance capital investments within the framework of a joint venture by Polish and French investors.

\section{Cooperation with the European Investment Bank}

In 1990 three credit lines were opened, namely, to finance a transport project, for the restructuring of the power-engineering sector and for financing small and medium sized projects in the economy. The total amount of the opened credit lines amounted to ECU $95 \mathrm{mn}$.

\section{Development and modernization of the banking system}

The year 1990 was a turning point in the process of the establishment of new banks. Numerous initiatives in this respect found their reflection in the decisions of the President of the NBP who granted, together with the Minister of Finance, 49 licences for the establishment of new banks in 1990.

Among the newly founded banks:

- $\quad 42$ had the form of joint stock companies with Polish capital

- $\quad 3$ had the form of joint stock companies with the participation of foreign capital

- 4 were cooperative banks, 3 of which were set on the basis of existing branches of cooperative banks

Among the newly established banks:

- $\quad$ in 23 banks the founding stock was contributed by legal persons

- $\quad$ in 25 banks there is mixed capital (contributed by both legal and natural persons)

- $\quad$ in 1 bank the stock was provided by natural persons exclusively

In 1990 the number of banks in Poland increased from 25 to 74 . In addition, there are also 1666 cooperative banks. In the majority of the banks the founders are planning a wide and universal service of economic activities conducted by natural persons as well as the service of small and medium- size economic agents in all ownership sectors. This is aimed at providing financial and organizational support for highly effective economic initiatives and enterprises in the macro-regions where the banks are based. 
Some banks provide for clear specialization in:

- $\quad$ supporting residential construction and public utilities provision

- $\quad$ serving the food-processing complex

- $\quad$ supporting the development of telecommunication services

- $\quad$ supporting economic initiatives aimed at alleviating the consequences of unemployment by creating new work posts

- $\quad$ serving firms connected with maritime economy

- $\quad$ serving for enterprises in the sugar industry

- $\quad$ serving of subjects conducting or undertaking activities in the scope of environmental protection

- $\quad$ supporting financially people conducting or undertaking private economic activity, participating in the process of restructuring the state property as well as supporting economic agents undergoing restructuring namely:

It should be stressed that the banks founded in 1990 include three with the participation of foreign capital,

- $\quad$ American Bank of Poland SA

- $\quad$ Raiffeisen-Centrobank SA (Austria)

- $\quad$ Scan-Bank Polish-Swedish Bank SA

The poor banking infrastructure inherited from the centrally planned economy was the main source of inefficiency and the cause of an inadequate level and scope of banking services. The change of this state of things required multi-directional actions. The first group of these actions includes immediate steps aimed at making direct contacts with the customer more efficient. Acting in this direction the NBP:

- $\quad$ extended the time of servicing customers in regional branches to 3 p.m. on working days and to 12 a.m. on working Saturdays

- $\quad$ opened afternoon foreign exchange and currency service for the population at least 3 times a week till 5 p.m. in regional offices.

- $\quad$ equipped work posts with basic information equipment and counting and sorting machines as well as provided adequate means of car transport

The second group of actions included steps aimed at accelerating monetary settlements between economic agents and between banks. NBP commenced works on the preparation of two complementary systems:

- $\quad$ electronic money transfer (EPP) called the electronic transfer of resources

- $\quad$ clearing house, i.e. an integrated network of regional centres of settlements between banks

In the autumn 1989 the NBP appealed to the IMF with a request for technical assistance which was to support efforts aimed at the modernization of the NBP. The assistance covered:

- $\quad$ development of the money market (the Bank of England)

- $\quad$ system of payments and settlements (the US Federal Reserve System)

- $\quad$ system of information and analysis (the Bank of Holland)

- $\quad$ banking supervision (the Bank of France)

- $\quad$ market and foreign exchange operations (the German Federal Bank)

\section{Economic performance}

The transformation of the Polish economy to a market economy resulted in significant changes in the Polish society. 
Poland experienced a recession which resulted in a reduction in gross domestic product (GDP) by 11.6 per cent. Investments were reduced by 10.1 per cent, while private consumption was reduced by 15.3 per cent; all in fixed prices. As a result of the reduction in the GDP, the unemployment at the end of the year was 1126000 or 6.3 per cent. This was also a year with hyperinflation. The consumer price index increased by $585.8 \%$, which means that the consumer prices increased almost seven times.

For the first time since 1971 Poland had a current account surplus; USD 668mn. The trade balance surplus amounted to USD $2064 \mathrm{mn}$. At the end of 1990 the debt in convertible currencies equalled USD 48.5bn.

\subsection{The year 1991}

The policy of deep changes of the Polish economic system towards market economy was continued in 1991. However, this transformation was carried on in circumstances of unfavourable outer situations and the existence of unfriendly internal factors. The domestic situation was shaped by such elements as, among others, collapse of economic cooperation with former COMECON's countries, transition to convertible currency cash settlements in foreign trade with the ex-Soviet Union and disturbances on the world market resulting from the Gulf war.

The most significant internal-nature factors impeding the changes having been made were as follows: parallelism of economic and political transformations, small experience in transition from centrally planned to market economy, incoherence of the legal system being expressed in simultaneous existence of regulations conformable with market principles as well as constituting a remainder of the old system and insufficient pace of adaptation of economic life participants and the public to new rules and facts occurring in the process of economy transformation.

The above-mentioned condition caused, among other things, that the following negative phenomena took place in 1991: further deepening of recession, unemployment growth, still worse and worse situation of the state budget and becoming worse financial standing of state owned enterprises.

In the course of 1991 the number of enterprises without credit-worthiness, i.e. those estimated by banks as being incapable of discharging the principal and interest in due time, significantly went up. In December 1991 the number of these enterprises, according to data provided by the largest twelve banks, amounted to 2880 , i.e. increased by 2332 units in relation to the previous year.

Among the positive occurrences noted in the economy in 1991 the following ones are worth mentioning: distinct slowdown of inflation, balancing consumer and supply markets, progress in privatization of state owned enterprises, dynamic development of private sector, growth in confidence in domestic currency, stabilization of foreign exchange market and development of capital market.

The main goal of the economic programme being performed since the beginning of 1990 was to stabilize the Polish economy and to transform it in a direction consistent with requirements of the market economy. In order to fulfil this programme certain steps were taken aimed at stopping the galloping inflation, purging and stabilizing the internal value of a currency. In 1990 introducing the internal convertibility of the zloty, further price liberalization and openness of the Polish economy to external co-operation took place.

In 1991 a greater stress was laid on ownership-institutional transformations in the economy, in this, first of all on the privatization process of state-owned enterprises. The 1991 year's privatization was conducted as follows:

- $\quad$ capital one, consisting in the transformation of enterprises into one-person state treasury companies and then the sale of their shares; mainly large-sized enterprises were privatized in this manner

- liquidation one, consisting in the liquidation of enterprises and then the sale of its property or the contribution of such property to a company; such method concerned, as a rule, medium- and small-sized firms 
For the capital-method privatization 250 enterprises were qualified, against 58 ones in 1990. Twenty of them were privatized against 6 units in 1990. On the other side, 878 firms were intended for privatization through liquidation, against 72 in 1990, while 198 enterprises were liquidated.

Apart from the two above described ways of privatization, in 1991 the introduction of sector oriented privatization programmes was initiated and widespread privatization was being prepared.

Besides privatization activities, the private sector was quickly developing due to the establishment of new businesses and increase of capital engaged, both Polish and foreign. At the end of December $1991 \mathrm{ca} .1 .5 \mathrm{mn}$ units run economic activity, i.e. about $0.3 \mathrm{mn}$ more than at the end of 1990 , and almost the whole increase concerned the private sector first of all private firms run by individuals.

Significant institutional changes took place in the capital market. Among other things the first session of the Warsaw Stock Exchange was held where stocks of the first five privatized enterprises were quoted.

Direct foreign investments in Poland constituted a next factor affecting the ownership-institutional structure of the economy. The Act on Foreign Investment Companies which liberalized regulations concerning contribution of foreign capital, establishment and operation of joint-venture companies, purchase of shares in privatized enterprises as well as transfer of profits and capital invested abroad was passed in June 1991. In December 1991, 4796 jointventure companies existed in Poland, i.e. 3151 more than at the end of 1990. Several companies fully owned by wide-known national and international investors. Furthermore, some foreign companies purchased significant stocks of shares of privatized state owned enterprises whereas foreign banks and insurance companies brought in their capitals in the banking-insurance sector. In spite of these investments the volume of foreign capital furnished to Poland was still not large being estimated at a level of USD 700mn at the end of 1991.

Apart from activities in the scope of ownership-institutional structure of the economy, there were regulatory changes which represented an important part of economic transformations taking place in 1991. The most significant of these changes were as follows:

- fundamental reform of public finance, in this among others, separation of local budgets from the state budget while voivodeship budgets were included into the central one; liquidation of over 30 central funds; introduction of new possibilities to finance current budgetary shortages by mean of treasury bills issue

- $\quad$ changes in the foreign trade system consisting, among others, in the movement to free-currency settlements of transactions with the former Soviet Union and other countries belonging to so-called First Payment Zone; amendments to the Customs Act and introduction of new EU-adjusted customs tariff on August 1, 1991, and unification of turnover tax rates on imported and home-manufactured products

In 1991 a quantitative expansion of the banking system still took place, though the number of granted licences significantly lowered in comparison with 1990. 18 licences on undertaking bank activities, against 45 in 1990, in this 4 concerned banks with the participation of foreign capital - 3 such licences granted in 1990. In 7 newestablished banks with domestic capital over 50 per cent of it constituted a private capital. Two full permissions of opening a branch of foreign bank were also granted.

The condition to obtain a bank licence was not changed in 1991. There were three requirements which had to be fulfilled:

- $\quad$ an appropriate banking experience of the managerial staff

- $\quad$ possession of sufficiently equipped physical facilities

- $\quad$ specified minimal initial capital (USD 6mn)

In total, at the end of 1991 licences were possessed by 86 commercial banks both active ones and being in the process of establishment. Therefore, the organizational structure of these banks was as follows: 
- $\quad$ central bank (the NBP)

- $\quad$ two state banks; the PKO-State Saving Bank and Bank for National Economy

- $\quad$ one state-cooperative bank; Bank for Food Economy

- 76 banks in the form of joint stock companies

- 7 joint stock banks with the participation of foreign capital

From among the existing commercial banks, 34 banks are private ones or with prevailing private capital. However, this number does not reflect the position of these banks in the Polish banking system. The role of "old" banks, established before 1990, is still dominating. The ten largest banks according to balance-sheet are in majority state treasury companies or state banks.

Fundamental changes of the ownership structure of the banking system were started through the initiation of privatization process of 9 large state banks established in 1989 on the basis of former branches of the NBP. The first stage of this process, taking place in 1991, consisted in the transportation of these banks into state treasury's companies.

In 1991 consortium loans appeared for the first time; several banks composing a consortium commonly granted credit which, considering the amount or risk of it, could not have been granted by any individual bank.

Organizational changes effected in 1991 referred to co-operative banks as well. At the end of 1991,1667 of them were assembled into four associating banks

- $\quad$ Bank for Food Economy (Bank Gospodarki-Zywnosciowej) comprising 1577 co-operative banks

- The Wielkopolski Economic Bank SA in Poznan (Gospodarczy Bank Wielkopolski SA w Poznaniu) comprising 61 co-operative banks, but with 250 bank-shareholders

- $\quad$ Bank of Economic Union SA (Bank Unii Gospodarczej SA) with 131 co-operative banks being its shareholders

- The Lower-Silesian Economic Bank SA in Wroclaw (Dolnoslaski Bank Gospodarzy SA we Wroclawiu)

An analysis of phenomena taking place in the banking system in 1991 showed the existence of dangerous trends consisting in the fast worsening quality of banks' loan portfolio. Considering these hazardous tendencies the General Inspectorate of Banking Supervision of the NBP, in co-operation with the Ministry of Finance, has worked out guiding principles for the creation of the general and specific provisions for bad loans. The introduction of these principles is to restrict possibilities in order to remove the risk from shareholders to banks' customers (depositors). In order to minimize depositors' risk and to establish an instrument eliminating crisis situations in the banking system, the creation of the system of deposit insurance was undertaken in 1991.

\section{Monetary policy}

In 1991 main interest rates used by the NBP, i.e. interest rate on the refinancing credit and rediscount rate, were shaped on the basis of the estimation of monetary policy results and the current economic situation, in this, among others, considering existing and forecasted inflation rates.

Several significant amendments to the policy of exchange rate shaped by NBP were introduced in 1991. A fixed exchange rate of the US dollar at the level of zls 9500 was maintained from January 1, 1990 till May 16, 1991. Only in May 1991 principles of shaping and the level of exchange rate were modified. The above-mentioned changes resulted from a need to increase profitability of Polish export and to lower the influence of fluctuations of US dollar exchange rate on foreign trade settlements. As of May 17, 1991 it was decided to leave the rule of the fixed exchange rate dependent on the US dollar only a new mechanism was implemented. Since that day a flexible exchange rate determined on the basis of so-called currency basket started to be binding. The basket was composed of five main convertible currencies, in proportion close to the geographical-foreign exchange structure of the Polish foreign trade turnover. Thus, the compositions of the basket were as follows: the US dollar in 45 per cent, German mark in 35 per cent, Pound sterling in 10 per cent, French franc in 5 per cent and Swiss franc in 5 per cent. Since 
May 17, 1991 the value of the basket was set at zls. 11100 per one US dollar and the exchange rate of this currency was the same, i.e. increased by almost 17 per cent. Simultaneously, it was assumed that the value of the currency basket would be stabilized at the level of zls 11100 while the zloty exchange rate to foreign currencies could change subject to fluctuations of quotations of the five above-mentioned convertible currencies in the international market.

The above regulations were in force till 14 October 1991. As of October 15 it was decided to renounce the stable value of the currency basket, not infringing its structure and the rule of its recounting on the basis of daily currency quotation in the international market, and implement crawling exchange rate. The new mechanism of the development of foreign exchange rates consisted in the constantly growing value of the basket by about zls 9 on each day (5-times per a week), yet in such a way so that a monthly depreciation of the zloty in relation to the basket did not exceed 1.8 per cent. This decision was justified by, among others, the necessity to maintain the profitability of Polish products export, protection of Polish manufactures against foreign competitors and creation of stable economic conditions for exporters, lowering a trade risk in virtue of jumping correction of the level of exchange rate.

\section{Economic performance}

In 1991 the GDP decreased by 7.6 per cent compared to 1990. The GDP was down mainly in the public sector whereas it considerably increased in the private sector. The same year private investments were reduced by 4.4 per cent, while private consumption increased by 6.3 per cent. The consumer price index increased on average by 70.3 .

At the end of the year the unemployment almost doubled from the previous year to 2155000 i.e. 11.8 per cent. The highest drop of employment, from main sectors of the economy, was noted in the agricultural, forestry and transport sector. At the end of the year, 62 per cent was employed in the public sector and 38 per cent in the private sector.

Investment expenditures in the economy were lowered by about 8 per cent. The above decline was connected with, among others, the debasement of incomes of economic entities and their use, primarily, as workers' wages. The above mentioned drop of expenditures resulted in a growing decapitalization of fixed assets to a poor quality of products.

Compared to last year exports increased by 18 per cent while imports increased by 47 per cent. This resulted in a substantial decrease in trade balance surplus from USD $2064 \mathrm{mn}$ to USD 287mn. The worsening situation was due to collapse of Polish exports to countries of Eastern and Central Europe due to their difficult economic situation, especially in former USSR, Poland's main trade partner for many years. With reference to import payments, the main factor influencing their increase was the high cost of fuel imports in convertible currencies. The second important reason of payments increase was the high import of consumer goods.

\section{$2.3 \quad$ The year 1992}

This year the first signs of an upturn in the Polish economy were observed, which at the beginning meant the reduction of output decrease and then a slight increase compared to the previous year. The GDP increased by 1.5 per cent.

Institutional and legal changes in the Polish banking system started in the second half of the 1980s. It took place within the framework of preparation to work in new conditions, after joining the International Monetary Fund and the World Bank among others. The actual reform of the banking system was implemented in 1989 (The Banking Law Act of January 31, 1989 and the Act of the NBP of January 31, 1989). The Act created a new legal framework of banking system activity. A concession of considerable supervision rights to the President of the NBP and making the introduction of prudential banking operations rules possible were also very important. The General Inspectorate of Banking Supervision started to play a main role in this process. 
This year an amendment to the banking legislation took place. The amended Banking Law Act strengthened the competence of banking supervision. The amendment of the Banking Law Act - valid from April 1992 - entitled the President of the NBP to grant, in consultation with the Minister of Finance, permissions for establishment of branches and representative offices of foreign banks within the territory of the Republic of Poland. In 1992 two permissions for opening representative agencies in Poland were given for

- "Westdeutsche Landesbank AG", Dusseldorf

- $\quad$ "Landesbank Hessen-Thuringen Girozentrale", Frankfurt/Main

At the end of December 1992 there were 19 representative offices of foreign banks acting in Poland.

In total, at the end of 1992 licences were possessed by 95 commercial banks both active ones and being in the process of establishment. Therefore, the organizational structure of these banks was as follows:

- $\quad 2$ state banks; the PKO State Savings Bank and the Bank of National Economy - BGK

- 1 state-cooperative bank; the Bank for Food Economy - BGZ

- 76 banks in the form of joint stock companies

- 5 cooperative banks

- 8 joint stock banks with the participation of foreign capital

- 3 branches of foreign banks

An analysis of phenomena taking place in the banking system in 1992 still showed the existence of dangerous trends consisting in, among others, a still increasing share of irregular liabilities in the granted credits, insufficient volume of reserves for risky assets, high concentration of credits, lowering profitability. The unfavourable financial situation of some banks resulted in binding them to work out and submit programmes of activities aimed at reaching a stable banks' condition. In two cases management by commissioners was implemented in commercial banks. One bank became supervised by another bank, stronger in respect of organization and finance. Motions to declare one commercial and two cooperative banks insolvency were tabled.

Apart from the creation of the National Clearing House SA, a number of actions concerning the banking system were undertaken in 1992. Establishment of TELEBANK SA, a banking telecommunication enterprise, constitutes one of such actions. The enterprise was founded by 17 Polish banks and started its full activity on November 30, 1992. Foundation of TELEBANK SA created a good basis to begin activities aimed at building up the telecommunication network supplying the needs of the entire banking and financial sector.

\section{Monetary Policy}

General directions of the monetary policy in 1992 converged with those used in the two former years were aimed at continuing the anti-inflationary policy and the protection of the zloty's position in relation to foreign currencies. To accomplish these goals, instruments of the central bank ensuring sufficient money supply to serve for all economic processes, to stimulate economic growth and not to intensify inflationary phenomena were used. While shaping money supply in the economy the NBP used the following instruments of the monetary policy: interest rate on credits granted to commercial banks, exchange rates, bank refinancing and obligatory reserve rate

The policy of exchange rate accepted in 1991 was continued in 1992. The main goals of this policy were as follows: keeping upward trend of foreign reserves being a guarantee of strengthening the trust to Poland as an economic partner and ensuring a possibility to repay foreign debts. Stimulation of growth of the economy's export abilities maintaining of competitiveness of Polish export offer and reduction of chances of inflationary impact of devaluation on the economy. In accordance with the policy, a mechanism of crawling devaluation of the zloty in relation to the basket of currencies has been introduced since October 15, 1991. The mechanism consists in constantly growing value of the basket, yet in such a way so that a monthly depreciation of the zloty in relation to the basket does not exceed 1.8 per cent per month. As of February 26, 1992 a 12 per cent jumping devaluation of the zloty in relation to the basket was made. The above decision was justified by unprofitable tendencies in foreign 
turnover visible at the end of 1991 and at the beginning of 1992 which resulted from, among others, lower profitability of Polish exports and a drop in foreign reserves.

\section{Economic performance}

For various reasons, the year of 1992 appeared to be a turning one for the Polish economy. Poland as the only country among ex-communist states, revealed a growth of GDP by 1.5 per cent in constant prices. This year the share of private sector in the creation of GDP was 47 per cent. In 1992 prices of consumer goods and services increased on the average by 43.0 per cent.

At the end of December there were 2509000 unemployed registered in employment agencies, i.e. 354000 more than a year ago. The unemployment rate was 13.6 per cent at the end of 1992. The highest drop of employment, from among the main sectors of the economy, was noted in agriculture, transport and forestry.

In December 1992 the number of enterprises without creditworthiness, i.e. those estimated by banks as being incapable of discharging the principal and interest in due time, amounted to 4 448, i.e. increased by 1558 units in relation to the previous year. In 1992 enterprises now losing their ability to discharge their liabilities and arrears in credit repayment were becoming mainly due to:

- $\quad$ still small demands for goods manufactured and service rendered

- $\quad$ buyers' delay in payments for delivered goods and services

- $\quad$ low profitability of enterprises because of high productions costs

- $\quad$ lost of liquidity by enterprises

It was a successive year of public finance crisis. The budgetary deficit was increasing as a result of encumbrances on social benefits, subsidies for communal services, public debt service and low profitability of the economy that had made a rise in budgetary income impossible. The budget deficit constituted 6.0 per cent of the GDP. 1992 also witnessed a drop of the volume of investment expenditures - they declined by 10.8 per cent, against 4.4 per cent in 1991 and 10.1 per cent in 1990. Trade balance showed a surplus of USD $856 \mathrm{mn}$. There was a negative balance of interest payments. The Balance of Payments in convertible currencies this year showed current account deficit amounting to USD $259 \mathrm{mn}$.

The privatization of state-owned enterprises was conducted at a lower pace than a year ago.

For the capital-method privatization 172 enterprises were qualified, against 250 in 1991 . Twenty-five of them were privatized. On the other side, 509 state-owned enterprises were intended for privatization through liquidation, against 878 in 1991 and 355 firms were liquidated. From August 1, 1990 till the end of 1992 the number of enterprises qualified for capital privatization totalled 480 units, 51 of which were privatized, 1459 plants were intended for liquidation during the same period and 617 of them were liquidated. On the basis of provisions of the Act on Economy of State Treasury's Agricultural Real Estates, a privatization through liquidation of agricultural properties belonging to the Resources of State Treasury's Agricultural Property was started. 539 units were qualified for privatization in this way.

\section{$2.4 \quad$ The year 1993}

Upward trends in the Polish economy noted since the second half of 1992 improved in 1993. GDP increased by almost 4 per cent. Industrial production and construction output went up, productivity and financial ratios of enterprises such as profitability increased. At the same time phenomena which might constrain the pace of economic growth also intensified. The process of restructuring slowed down. Enterprises, similar to previous years, were reluctant to make investments. The public finance crisis intensified and the danger of potential inflation surged as well as high unemployment rate still existed. 


\section{Monetary Policy}

In the first quarter of the year the interest rate was reduced by almost 10 per cent or 3 per cent points. This decision was justified by the following facts: lower than forecasted indices of price growth, the forecast for inflation to be at low level in the following months and significant lowering of interest rates on the interbank market in January 1993.

This year the exchange rate policy adopted in 1991 continued. The basic aim of this policy was first of all to limit the possibility of inflationary influence of zloty devaluation on the economy. Additionally, the need to keep a safe level of foreign reserves was taken into account; these reserves guarantee confidence in Poland as an economic partner and create the possibility to pay out foreign debt. To keep the Polish economy able to export and to maintain the competitiveness of the Polish exports offer was also an important assumption. According to the principles of this policy, devaluation of the zloty exchange rate in relation to the basket of 5 currencies occurred at pace rate. The devaluation was kept at the planned rate of an average monthly devaluation at the level of 1.8 per cent. The aim of this was to keep a real value of the zloty in relation to the currencies of the most important trade partners, with a much higher rate of inflation in Poland than in other countries. As a result of the tendency of appreciation of the zloty during the summer, a decision was taken in August 1993 to devaluate the zloty by 8 per cent in relation to the basket of 5 currencies.

\section{International activity of the National Bank of Poland}

The NBP borrows from the World Bank for the implementation of the following programs:

- $\quad$ development of industry

- $\quad$ development of agricultural and food industry

The NBP performs duties of a financial agent of the government to a full extent as regards two loans

- $\quad$ development of agriculture

- development of financial institutions

In 1993 four credit agreements were signed with the World Bank - credits granted by the WB - for the total of USD 1046 million:

- $\quad$ Roads; the aims of this credit are the modernization of public roads and improvement of the management of their exploitation

- Program of agricultural sector adjustment loan. The loan is aimed to support the infrastructure of agricultural market, the introduction of telephones in rural areas, water supply in rural areas as well as development of small manufactures in this sector

- Program of enterprise and financial adjustment loan. The loan is aimed at the implementation of the program of financial restructuring of enterprises and banks.

- Forestry development; the loan is aimed at afforestation and reconstruction of destroyed forests, intensification of care intervention, afforestation of the weakest and environmentally degenerated areas and the improvement of the management system

The European Investment bank (EIB) granted three loans in 1993:

- $\quad$ Forestry Development

- A credit loan for the Polski Bank Rozwoju SA, assigned for investment projects undertaken by small and medium size enterprises

- $\quad$ Railway II; a loan on the modernization of the Warsaw-Berlin railway, to adjust it to the European standards 
The European Bank for Reconstruction and Development granted loans both to the private and the public sector. One loan for the public sector was the development of highways.

Cooperation with the Credit Nationale. The loan is of very preferential nature, only Polish-French companies may be the borrowers of this loan.

\section{Economic performance}

This year the GDP increased by 3.8 per cent in constant prices, with a systematically growing share of the private sector in its production, which exceeded 50 per cent.

In spite of a slight improvement in corporate financial performance there was an increase in the number of businesses in bad financial standing. At the end of December, 5764 had lost their credit capacity from 4448 one year earlier.

1993 witnessed a stabilization of employment in the national economy of about 11.3 million people, with a vital change in the structure of employment, namely a decrease in employment in the public sector, by 0.5 million, and a parallel increase in employment in the private sector. The year was characterised by a further growth in unemployment, to approximately 2890000 at the end of the year i.e. 15.7 per cent. Regional differences in unemployment rates became deeper. The rise of unemployment in individual provinces was from about 7 per cent (Krakow province) to almost 29 per cent (Koszalin province).

In 1993 there was a 9 per cent growth in the number of enterprises run by natural persons, and a 50 per cent increase in the number of joint ventures with foreign participation. As a result of these processes, as compared with 1992, production in private industry was almost 35 per cent higher, and its share in total industrial production increased by almost 31 per cent in 1992 to above 37 per cent in 1993.

Investments increased by 2.6 per cent compared to last year, while private consumption increased by 5.5 per cent. The same year the inflation rate was 35.3 per cent

Exports was almost 3 per cent lower and imports almost 18 per cent higher this year compared to last year, and the deficit of the trade balance amounted to USD $1924 \mathrm{mn}$. The balance of current account was negative and amounted to minus $2329 \mathrm{mn}$ USD.

\subsection{The year 1994}

Economic results of 1994 show further strengthening of growth tendencies in the economy. The basic element of the developing economic situation was first of all the high dynamics of sold industrial production, while there was stagnation in construction-assembling production and a serious drop in agricultural production. The GDP went up more than 5 per cent in constant prices.

The adjustment of Polish production to European standards and export-oriented measures of the government, also had its positive effect on Polish export competitiveness.

This year the NBP completed its domestic currency reform that started on January 1, 1995 and was finished at the end of 1996. The new notes were reduced to 0.1 per cent compared to old notes in nominal value.

\section{Monetary policy}

Due to less inflation than previous years, the interest rate was reduced two times; in May and November.

In 1994 the exchange rate policy of NBP was the continuation of principles adopted in 1991. The most important prerequisite of exchange rate policy was as formerly the effective joining of two aims which were competitive to each other; reducing the inflation tendencies in the economy and the necessity to maintain the safe 
level of foreign reserves as the guarantee of confidence in Poland as an economic partner. In the second half of 1994 the pace of the average monthly zloty devaluation was lowered, and at the end of the year it was about 1.4 per cent.

The decision on the rate of devaluation was first of all determined by the intensification of inflation impulses coming from the development of the Polish economy which had been maintained for two years. In 1994 the source of inflation tensions on the domestic market was among other things, the high dynamic of external demand rise, due to substantial economic growth in the EU countries.

\section{Economic performance}

The GDP rose by 5.2 per cent in fixed prices. The personal sector share in its generation rose from almost 48 per cent in 1993 to above 56 per cent in 1994.

In industry the volume of sold production rose by almost 12 per cent in 1994 in relation to about 7 per cent in 1993 and 4 per cent in 1992.

There was a strengthening of growth tendencies in relation to investment in the economy. The real growth in 1994 amounted to about 6 per cent while in the period 1992-1993 it amounted to 0.7 per cent and 2.2 per cent. The high growth rate can be noted in relation to investments on machines, equipment etc., which indicates the strengthening of modernization processes in the Polish economy.

The noted improvement of the economic situation favoured the creation of new jobs, especially in the private sector. By the end of the year it was possible to stop the declining tendency of employment in the economy which was maintained since the beginning of the nineties. By the end of December 1994 the unemployment was 2838000 i.e. 16.0 per cent of the labour force, a decline by 52000 from one year earlier.

The inflation rate this year was 32.2 per cent. The inflation was affected mostly by the rise in food prices and rise of officially and centrally regulated prices.

In 1994 exports increased by 24 per cent. The increase in receipts was, on the one hand, associated with the economic upswing in Poland's main trading partners, i.e. the EU countries, and on the other hand, with the adjustment of domestic producers to the requirements of external markets. Foreign trade was also stimulated by export promoting efforts of the government, among other things, in the form of investment tax credits for exporters. Imports increased by more than 10 per cent this year, and the trade balance showed a deficit amounted to USD $779 \mathrm{mn}$. The current account had a deficit amounted to USD 949mn, a significant improved situation compared to 1993.

Poland's foreign debt in convertible currencies as of the end of December 1994 totalled USD 42 174mn, i.e. was by USD $5072 \mathrm{mn}$ lower compared to the end of 1993 . The reduction was among others based on the reduction agreement with 17 Paris Club countries, and London Club countries.

\subsection{The year 1995}

This year has been the year of the greatest economic success so far in this decade as the GDP increased by 7 per cent. The developments were accompanied by a further decrease in inflation rate and of unemployment.

The economic boom starting in 1992 resulted from economic reforms introduced at the beginning of the 90 's. From among the factors directly contributing to the 1995 economic expansion should be mentioned the growth of exports and the growth of business investments expenditures.

On May 16, a new exchange rate mechanism was brought into operation. It resulted in an increased role of market mechanisms and in higher flexibility of the exchange rate system. The exchange rate set by the NBP constitutes a central reference rate for the permissible band of divergence in market rate - \pm 7 per cent points - with the NBP committed to maintaining these within this band. The central reference rate (parity rate) remains subject to 
crawling devaluation. From February 16 to the end of the year, the average monthly pace of devaluation was set at around 1.2 per cent from 1.4 per cent.

\section{International activity by the National Bank of Poland}

Some of the international activity to NBP is to coordinate the collaboration of the Polish authorities and the NBP with international institutions. In 1995, as in the previous year, collaboration with the World Bank concentrated on adjustments and revision to existing loan programmes and the search for new forms and opportunities of cooperation. The forms of financial collaboration with the World Bank and the areas of the economy to be supported by World Bank loan programmes in Poland were specified in a new strategy for Poland development in 1994. In accordance with the programme, the activities of the World Bank in relation to Poland primarily focus on providing assistance to:

- $\quad$ the power and energy sector including the modernization of transmissions lines, the restructuring of the coal and gas industries, geothermal power projects, and investments in generating capacity, new power transmission facilities and project for the privatisation of power companies

- $\quad$ the transport infrastructure; the modernization of port facilities, construction of the motorway network and restructuring of Polish railways

- $\quad$ privatisation; transformation in the public sector and self-government reform (post-privatisation, the reform of commercial registers support to municipal utilities, a public-sector adjustment loan, the modernization of tax administration)

- $\quad$ agricultural and rural economy activity; the privatisation of state farms, the development of the wholesale market and commodity exchanges, support to the system of financing rural economic activity

- $\quad$ social projects (financing to the health service, education)

At the end of 1995 there were twelve projects under preparation, to a total value of USD $1166 \mathrm{mn}$.

An important role in the development of the private sector is played by the International Finance Corporation (IFC), an organisation affiliated to the World Bank, established to support private sector development. In contrast to the World Bank, the IFC is free to make loans and take up equity without any need to obtain government guarantees. A significant element in the activity of the IFC is the arrangement of co-financing for particular projects from international financial institutions, domestic and foreign companies and commercial banks. In 1995, the IFC granted six loans totalling almost USD 78mn to Polish companies, principally in the telecommunication, gas and retail distribution industries. By the end of the year, the overall amount of IFC loans and investments in Poland stood at USD $291 \mathrm{mn}$.

By the end of 1995 another organisation affiliated to the World Bank, the Multilateral Investment Guarantee Agency had extended guarantees totalling USD 55mn to nine projects in Poland. One of this related to the banking sector, while the others involved the development of private agricultural production of small and mediumsized manufacturing facilities.

Collaboration with the European Bank for Reconstruction and Development (EBRD) in 1995 concentrated on adjusting the form and scope of the Bank's activities to Polish requirements and conditions, while seeking to make maximum use of the possibilities presented in the Bank's Articles. The Bank's basic mission is to support the transmission to the market economy, while taking into account the needs and priorities of the Polish economy. In previous years, the following measures had been taken:

- $\quad$ supporting the development of the private sector through loan finance and investments in Polish companies, without requiring governmental guarantees

- $\quad$ financing investment projects of a substantially innovative character

- $\quad$ supporting the development of the financial sector

- $\quad$ supporting the development of the institutions essential to a market economy

- $\quad$ increasing the Bank's capacity to operate effectively in Poland, one measure being to expand the Bank's Warsaw office 
Poland is second to Russia in terms of the number of projects financed by the EBRD, and third in terms of their value, after Russia and Hungary.

\section{Economic performance}

The strong demand both domestic and abroad resulted in a significant increase in the GDP at 7.0 per cent. This year the private consumption increased by 3.7 per cent.

In the second half of the year there was an appreciation of the zloty. This resulted in a decrease in the inflation rate during the year. From 1994 to 1995 the consumer prices increased by 27.8 per cent, while one year earlier the inflation rate was 32.2 per cent.

Thanks to a strong performance of the Western economies and raising productivity in Poland, there was a strong rise in exports, almost 37 per cent from previous year. The same year the imports increased by almost 40 per cent due to the present economic activity in Poland. The trade balance showed a deficit of USD $1667 \mathrm{mn}$ compared to a deficit one year earlier of USD $779 \mathrm{mn}$. The current account had a deficit at USD $2299 \mathrm{mn}$, an increase from USD 994mn the previous year.

The positive development in the Polish economy resulted in a fall in the unemployment rate at the end of the year of 14.9 per cent or 2629000 , compared to 16.0 per cent or 2838000 one year earlier.

The fiscal deficit this year constituted 2.6 per cent of the GDP. It was thus under the 3.0 per cent cut-off that represents one of the convergence criteria contained in the Maastricht Treaty. Nevertheless, it should be noted that when we include outstanding liabilities owed by central government institutions, the deficit represents 3.4 per cent of the GDP.

\section{$2.7 \quad$ The year 1996}

The year 1996 primarily brought positive tendencies in the Polish economy, with these mostly representing an extension of processes seen in previous years. Poland continued to have one of the fastest growing economies in Europe, with declining unemployment and falling inflation rate. The GDP increased by 6.0 per cent in fixed prices, while the inflation rate was 19.9 per cent, compared to 27.8 per cent the previous year.

\section{Monetary Policy}

This year brought a change in the operational target of Polish monetary policy. Instead of stabilizing shortterm interest rates, the target became controlling the growth in reserve money stock. Since it is impossible to control the money supply and the interest rates simultaneously the latter were allowed to move in accordance with the free play of supply and demand on the money market. In other words, interest rate policies were subordinated to the objective of controlling the supply of reserve money stocks and money supply in general. This approach leads to greater volatility in market rates.

The NBP lowered its base lending rates two times; in January and July. The decision to cut official lending rates in January was taken in response to rising foreign demand for Polish Treasury bills which was swelling the money supply. The decision was also influenced by the fact that the inflation had been falling systematically in the last quarter of 1995, and a further drop was expected in 1996.

This year was the first full year under the uniform exchange regime introduced in May 1995. The exchange rate for the zloty was set on the interbank (FX) market within a 14 per cent band of permissible divergence from parity. At the same time, the crawling devaluation of the central reference rate continued. On January 8, 1996 the average monthly devaluation of the parity rate against Poland's reference basket of currencies was lowered from around 1.2 per cent to 1.0 per cent. 


\section{International activity by the National Bank of Poland}

For several years now, the activities of the World Bank in relation to Poland have primarily focussed on the power and energy sector, transport infrastructure, privatization, transformation in the public sector and selfgovernment reform, agriculture and rural economic activity, and social projects. In 1996 the World Bank extended three loans to Poland, which refer to the power sector, transport and municipal services.

Collaboration with the European Bank for Reconstruction and Development (EBRD) in 1996 was marked by a surge in its investment in the development of Poland's private sector. The prioritised areas of activity for the EBRD in Poland were mapped out in a new "Strategy for Poland" drawn up in mid-1996; these comprise: further involvement in financing private-sector ventures of local significance in order to bolster the economics of particular regions and reduce the disparities in their level of development; participation in corporate privatisation and restructuring; further support to the development of the financial sector, including insurance companies and the cooperative banking system; new capital investment in infrastructure projects, above all in telecommunication and transport; and the financing of environmentally friendly projects in industries that are detrimental to the natural environment. In all, the EBRD is financing 51 projects in Poland to the total value of 790mn Ecu.

In 1996 the European Investment Bank (EIB) extended three loans to Poland: the Highways Project (100mn Ecu), the Polish Oil and Gas Company (PGNG) - Second Gas Project (180mn Ecu), and Polish Telecommunication I \& II (100mn Ecu). Altogether, the EIB has granted 18 loans to Poland totalling $1384 \mathrm{mn}$ Ecu.

\section{Economic Performance}

The trade balance shows a significant increase in the deficit compared to previous year: USD $8363 \mathrm{mn}$, which represents 5 times the deficit reported in 1995. Imports increased by more than 30 per cent, while exports rose only 7 per cent. The deficit amounted to 6 per cent of GDP. The same year the current account deficit was USD $1352 \mathrm{mn}$. The main reason for this development was the economic downturn being experienced by Poland's principal trading partners - the countries of the European Union - which resulted in a fall in the demand for imported goods, including Polish goods. A particular negative impact was produced by the weakening of growth in Germany, Poland's single largest trading partner. Another factor of some significance was the increase in domestic demand, which reduced incentives to develop production for exports. The high increase in imports can above all be traced to the growth of internal demand. Investment grew by 19.7 per cent, while private consumption grew by 8.7 per cent in fixed prices. The acceleration of consumption growth was due to an increase in real personal disposable income and decline in the portion of income allocated to saving. Another significant factor stimulating imports was the lowering of customs duties and border taxes.

There was a strong increase in foreign direct investments compared to last year, up 150 per cent to USD $2768 \mathrm{mn}$. The surge in incoming direct investments was the result of a variety of factors. An important role was played by the privatization performed in 1996 and the participation in these by foreign investors. Another powerful stimulus to foreign investment was the very sound financial performance of companies in which foreign direct investment had taken place in previous years. A significant macroeconomic factor encouraging foreign investment was the strong performance of the whole Polish economy and optimistic projections concerning its further growth. In importing modern capital goods, and also materials and intermediates, these companies were bolstering the future export potential of the Polish economy.

Poland's foreign debt as a result of credits received and debt securities issued - bonds issued to the creditors of the London Club, and also Eurobonds - amounted to USD $40558 \mathrm{mn}$ on December 31, 1996. This represented a drop of USD 3 399mn on year end 1995.

Due to the strong economic growth the number of unemployed was 2360000 i.e.13.6 per cent, compared to 2629000 or 14.9 per cent one year earlier.

The high rate of economic growth, lower inflation, and also the improved financial condition of the personal sector, led to a favourable situation as regards government revenues. The fiscal deficit constituted 2.5 per cent of GDP. 


\subsection{The year 1997}

This year the Polish economy once again had a significant growth. Poland's GDP rose by 7.1 per cent, giving the country one of the fastest growing economies in the world.

The difference between aggregate demand and domestic supply was made up by imports, which resulted in increased deficit on the trade balance and on the current account.

To curb the growth in domestic demand and to avoid increased inflation-pressure the NBP raised its base rates in August. This year the inflation was 14.9 per cent per cent compared to 19.9 per cent last year.

The year 1997 brought major advances in harmonising Polish legislation with the standards applicable in the EU. A new Constitution of the Polish Republic was adopted, which brought the standard of the NBP more into line with EU norms, e.g., by reinforcing the independence of the central bank, prohibiting the financing of the fiscal deficit by borrowing from the central bank, and instituting a collective mechanism for the formulation of monetary policy by establishing the Monetary Policy Council (MPC).

The current account of Poland showed a deficit this year amounting to USD $4268 \mathrm{mn}$, an increase by almost $3000 \mathrm{mn}$ from last year. The prime cause of such a profound current deficit was the deterioration in the trade balance. This year imports increased by almost 16 per cent while exports increased by around 11 per cent, which resulted in an increased deficit on the trade balance by USD $2601 \mathrm{mn}$, to USD $10964 \mathrm{mn}$. The sharp rise in imports is the result of the maintenance of strong domestic demand within the Polish economy.

Foreign direct investment totalled USD $3077 \mathrm{mn}$, as against USD $2768 \mathrm{mn}$ in 1996. One of the sources of inflows from abroad were payments in the second half of 1997 connected with the privatization of large state enterprises: Bank Handlowy w Warszawie SA, the KGHM "Polska Miedz" - Copper Mining and Smelting Combine, and Powszechny Bank Kredytowy SA.

The strong increase in demand, where fixed capital formation and private consumption increased by 21.7 per cent and 6.9 per cent respectively, led to a significant decrease in unemployment. Unemployment went down by 534000 people, from 2360000 to 1826000 or 10.3 per cent by the end of the year.

\subsection{The year 1998}

The year 1998 was a difficult year for Poland. As a result of financial and currency crises that engulfed the world last year - most particularly the Russian crisis - there was a reduction in the growth rate of the economy and an increased deficit in the trade balance and the current account.

In the beginning of 1998 a new act of the National Bank of Poland took effect. From this moment decisions on monetary policy measures are taken by a ten-member Monetary Policy Council (MPC).

\section{Monetary policy}

This year was the first in which the strategy of pursuing a direct inflationary target was implemented. The Council's decision to abandon the use of money supply growth as the official intermediate monetary policy target is attributable to the fact that the correlation between the M2 monetary aggregate and inflation was becoming increasingly less stable and predictable. The inflation target from December 1997 to December 1998 was 9.5 per cent. The actual price increase this period was 8.6 per cent. On average from 1997 to 1998 the inflation rate was 11.8 per cent. $1999-2003$ sees the fulfilment of annual monetary policy targets as successive stages in reaching the central medium - term monetary policy objective of bringing inflation to below 4 per cent by the year 2003 . The monetary policy of the NBP was geared to pursuing the inflationary target by using the various instruments at the disposal of the central bank, such as interest rates, exchanges rates - lowering the rate of monthly devaluation under the crawling band mechanism and broadening the trading band around central parity - and also regulatory reserve requirements and refinancing facilities. An additional consideration factored into the decisions of the Monetary 
Policy Council was the need to close the gap between the growth of domestic demand and the GDP. The NBP influenced interest rates during the year both directly via the rates offered on open market operations, and indirectly, through the rate on Lombard facilities. The purpose of this was to adjust interest rates in line with the threat of inflation.

From the second quarter inflation was declining and domestic demand growth was also slowing. Due to these circumstances the Council reduced the interest rates both in May and July. Due to the further rapid decrease in both ongoing and forecast inflation and the diminishing pace of domestic demand growth, yet another decision was made to cut rates; this time from October. The same factors as in October lay behind the next cut in NBP base rates in December this year.

The mechanism for setting zloty exchange rates against other currencies remained unchanged in 1998. The regime in place continued to be that of a crawling band used to determine the permissible deviation of market exchange rates from central parity. In view of the visible decline in inflation and the need to impact inflationary expectations, the MPC cut the monthly rate of crawling devaluation three times this year, lowering it from 1 per cent to 0.8 per cent February 26, to 0.6 per cent on July 17, and to 0.5 per cent on September 10 . At the same time, to allow exchange rates to move more freely, the MPC also broadened the permissible trading band relative to central parity on two occasions: on February 26 it was extended from \pm 7 per cent to \pm 10 per cent and on October 28 to \pm 12.5 per cent.

\section{Economic performance}

The second half of the year brought a certain weakening of business activity, with the result that GDP growth for the year as a whole stood at 5.0 per cent. One of the prime factors at work in slowing down growth was the slacker increase in demand seen in the final months of the year, principally in external demand. This situation was primarily the indirect effect of turmoil on global financial markets, and particularly of the Russian crisis, which caused a grave collapse in Polish exports to especially Russia and Ukraine.

As a result of the difficult situation in the export sector the trade balance deficit increased by USD $3213 \mathrm{mn}$ compared to the previous year to a deficit amounted to USD $14228 \mathrm{mn}$. Exports increased by USD $2847 \mathrm{mn}$, while imports increased by USD 6 060mn. The current account deficit rose from USD $4268 \mathrm{mn}$ in 1997 to USD $6858 \mathrm{mn}$ in 1998. The shortfall on the current balance indicates that the aggregate growth in domestic demand was higher than the growth in GDP.

There was a significant increase in FDI, which totalled USD $5129 \mathrm{mn}$. This trend suffered a major disruption as a result of the Russian crisis in August. Foreign direct investors continued to view the Polish economy as stable and offering sound growth prospects. The industries receiving the most FDI were the financial sector and the car industry. One of the factors encouraging investment in the banking industry was that it was seen as a very good bridgehead for gaining a strong position on the Polish pension fund market. This year both Fiat and Volkswagen established their own banks in Poland to finance purchases of their cars. The largest investments in the car industry were Fiat and Daewoo, both undertook capital expenditure in the course of 1998 to prepare the production of new models of vehicles.

Even with a growth in GDP by 5.0 per cent, where private consumption also rose by 4.8 per cent and private investments rose by 14.2 per cent, the unemployment at the year end had risen to 1831000 people or 10.4 per cent.

The ratio of the fiscal deficit to GDP came to around 2.4 per cent this year against 2.7 per cent in 1997 and 3.4 per cent in 1996.

\subsection{The year 1999}

This year was one of the most difficult in the ten-year history of systemic transition in Poland. There were two factors that made this year a difficult one. Firstly, Poland felt the full repercussions of the financial and 
economic crises that had taken place in earlier years in various parts of the world, and also of the overall slowdown in world growth and the increase in world oil prices. Secondly, it was during this period of slackening growth, at the beginning of 1999, that Poland launched four public sector reforms which are of great importance to long-term economic growth, but are also costly, namely, an administrative reform linked to the decentralisation of government, a pension reform, a health service reform, and a reform of primary and secondary education. Despite the difficulties this year the GDP increased by 4.5 per cent and the inflation rate was reduced to 7.3 per cent.

\section{Monetary policy}

In the first two months of the year, inflation came down, which is attributable to the maintenance of excess supply, primarily of foodstuffs, caused by the loss of Eastern markets in the wake of the Russian crises. Given that inflation was expected to decline further in 1999 the base interest rates were cut on January 21.

The real course of economic developments subsequently differed from that projected by the Monetary Policy Council. In the second half of the year, inflation began to gather speed fairly quickly, chiefly due to higher fuel and food prices. World oil prices rocketed and foodstuff prices rose more rapidly than overall inflation due to the worse harvest in many years. As a consequence interest rates were increased both on September 23 and on November 18.

In 1999 zloty exchange rates continued to be subject to the same crawling band regime, consisting in crawling devaluation against a reference currency basket in conjunction with a trading band for permissible deviation in market exchange rates. However, owing to the launch of the single European currency, the Euro, the compositions of the reference basket was altered. Pursuant to a decision of the Council of Ministers and the Monetary Policy Council as of January 1, 1999, the composition of the basket was set at 55 per cent euro and 45 per cent US dollar.

In 1999 the NBP took preparatory steps with a view to fully floating the Polish currency. Thus, as of March 25 , the monthly rate of crawling devaluation was lowered from 0.5 per cent to 0.3 per cent, thereby adjusting it to correspond to the new inflation target for 1999 and to reflect the narrowing differential in price growth between Poland and other countries. In parallel with this, the trading band for permissible fluctuation of NBP market rates relative to central parity was extended from \pm 12.5 per cent to \pm 15 per cent.

\section{Economic performance}

The current account deficit increased by more than USD 4 700mn from last year to USD $11568 \mathrm{mn}$. This was due to a reduction in exports by USD $4143 \mathrm{mn}$. The main reason for the widening trade gap should be sought in the collapse of exports to countries of Central and Eastern Europe, particularly Russia and Ukraine. Imports was reduced by USD $2367 \mathrm{mn}$, and the trade balance showed a deficit of USD $16004 \mathrm{mn}$, compared to USD $14228 \mathrm{mn}$ one year ago. One factor stimulating imports, despite the decline overall, was the large inflow of foreign direct investment. These investments were coupled with the transfer of modern technologies, which spurred an increase in imports of goods and services.

The ensuing inflow of capital came to USD $6471 \mathrm{mn}$ over the whole of 1999, giving an increase of USD $1342 \mathrm{mn}$ compared to the previous year. The most significant component of direct equity investment was receipts from the privatisation of Polish companies and banks.

Even with a growth in the GDP by 4.5 per cent, there was rising unemployment, especially in the last quarter of the year. Unemployment rose by 519000 people to 2350000 i.e. 13.0 per cent. 


\section{THE SECOND DECADE}

\subsection{The year 2000}

The year 2000 brought contradictory tendencies within the Polish economy. The negative tendencies observable primarily included a slowdown in economic growth from one quarter to the next, a rising government deficit and mounting unemployment.

As regards positive developments, there are two that deserve particular mention. The first was restoration of control over inflation. The turnaround in inflation was achieved thanks to a sharp tightening of monetary policy, with inflation beginning to tend downwards from August 2000. Slowing down growth in aggregate demand produced another positive effect, namely a narrowing of the current account deficit. This was due to reduced increase in private consumption and investment demand.

The average inflation rose from 7.3 per cent in 1999 to 10.1 per cent in 2000. The inflation accelerated in the final months of 1999 as a result of further growth in domestic demand due to relaxation of macroeconomic policies. The quickening of inflation in the latter half of 1999 was also connected with powerful supply disruptions on the fuel and food markets. The increase in world oil prices triggered 20 per cent rises in domestic fuel prices. Meanwhile, the increase in foodstuff prices was related to poorer agricultural output in 1999, traceable to adverse weather conditions, while at the same time stiff protection against imports was afforded to the domestic market for agricultural produce.

In January 2000 , consumer inflation climbed to 10.1 per cent compared to January 1999 , thereby hitting double figures for the first time in almost one and a half year. For this reason in February, the Monetary Policy Council decided to raise interest rates. Despite a tougher monetary policy, the inevitable time lag between monetary measures and their impact on inflationary processes meant that for seven months of the year 2000 CPI inflation ran in excess of 10 per cent, peaking in July at 11.6 per cent. To prevent a consolidation of inflation expectations and their spill over into wage growth, the MPC raised interest rate again in August.

The exchange rate regime in Poland changed in 2000. On April 11, the Council of Ministers, acting in consultation with the MPC, took the decision to float the zloty, which signified the abolition of the central parity rate for the zloty, and also the crawling band mechanism to a reference currency basket, with its trading band for permissible deviations in market exchange rates from central parity. The resolution introducing these changes took effect on April 12, 2000. Following the change in the exchange rate regime, the National Bank of Poland continued to refrain from intervention in the currency market. Zloty exchange rates thus ceased to be employed as a monetary policy instrument. In the long run, it is not possible to influence interest rates with a view to achievement of the inflation target while at the same time controlling exchange rates.

Compared to last year the deficit on the current account was reduced by USD $1591 \mathrm{mn}$ to USD $9978 \mathrm{mn}$. This was due to reduction in the deficit on the trade balance by USD $1155 \mathrm{mn}$ to USD $14849 \mathrm{mn}$. Exports increased by USD $2115 \mathrm{mn}$ i.e. by 7.1 per cent, while imports increased by only USD $960 \mathrm{mn}$ i.e. by 2.1 per cent. Exportgrowth in 2000 was the result of the following:

- External factors: the year 2000 saw the world economy pick up. The increase in global demand led to an expansion of world trade. The global increase in import demand caused demand for Polish export to rise as well.

- Internal factors: the positive effects became apparent of export-oriented investment by foreign direct investors, the best example being the launch of the manufacture and export of diesel engines by the ISUZU companies. In addition, domestic demand growth weakened, compelling companies to seek sales markets abroad.

The growth in imports was primarily linked to the higher value of oil imports, a consequence of rising world oil prices. 
This year the foreign direct investments amounted to USD $8291 \mathrm{mn}$, an increase by 28 per cent compared to last year. The prime reason was the sale by the Treasury of a 25 per cent equity interest in Telekomunikacja Polska SA (TPSA) to France Telecom. This constituted the second stage of the privatisation of TPSA, following the sale of a 15 per cent holding in 1998.

Even with a growth in the GDP by 4.2 per cent there was a significant increase in the level of unemployment also this year. At the end of the year the level of unemployment had risen by 353000 people to 2703000 or 15.1 per cent, and represented probably the biggest problem in the development of the Polish economy.

\subsection{The year 2001}

Except from 1990 and 1991, this year was so far probably the most difficult in the process of economic transition. The GDP grew by only 1.1 per cent compared to last year, due to a slower growth rate in the private consumption than previous year and a significant reduction in gross fixed capital investments. The reduction in investments was probably among others the result of a slow-down in international economic growth and the terror attack in USA. The reduced growth rate in the GDP resulted in a significant increase in the already high level of unemployment. By the year end the number of unemployed was 3115000 people or 17.5 per cent compared to 2703000 one year ago, i.e. the number had increased by 412000 .

At the end of 2001, the twelve-month Consumer Price Index stood at 3.6 per cent, the lowest level since mid-1970s. Annual average inflation came to 5.5 per cent in 2001, as against 10.1 per cent the year before. The downward trend in the inflation rate was a result of low food price growth and a decrease in fuel prices. The fall in inflation was also helped by the zloty appreciation; 8.5 per cent against euro and 5.8 per cent against dollar.

The rapid and unexpected decline in economic growth and in inflation that began in the second quarter of 2001 led the Monetary Policy Council to lower the NBP base interest rates six times in the course of 2001, by a total of seven and a half points. The result was that nominal NBP interest rates were brought down to their lowest level since the start of systemic transition.

Due to low economic growth in 2001, this resulted in a growth in imports by only USD 300mn compared to last year. However there was a significant growth in exports due to a relatively strong economic growth within the European Union until the first quarter of 2001. Exports increased by USD $2503 \mathrm{mn}$, which resulted in a decrease in the trade balance deficit by USD $2198 \mathrm{mn}$ to USD $12651 \mathrm{mn}$ this year. The current account deficit was also reduced compared to last year as a result of the increase in exports; the deficit was reduced from USD $9978 \mathrm{mn}$ in 2000 i.e. 6.3 per cent of GDP to USD $7166 \mathrm{mn}$ in 2001 or 4.1 per cent of GDP.

The inflow of direct investment to Poland stood at USD $6995 \mathrm{mn}$. This represented a decrease of USD $1298 \mathrm{mn}$ compared to 2000. At the end of 2000, the Treasury sold a large equity interest in Telekomunikacja Polska SA (TPSA) to France Telecom. This single transaction was responsible for the much larger balance of foreign direct investments in 2001.

\subsection{The year 2002}

This year was another difficult year for Poland. Like last year there was a low level of growth in the GDP, only 1.4 per cent, and a rising unemployment, from an already high level.

The economic growth rate, slightly higher than 2001, was a result of decreasing industrial output trend being overcome in Q3 and Q4 of 2002. Apart from the increased private consumption, this resulted from good exports figures, with exports increasing despite poor foreign demand, particularly in Germany where a recession was noted. A fall in fixed capital formation by almost 6 per cent had a negative impact on the economic growth. This can be traced to pessimistic assessments of future demand, caused by the global economic slowdown and slow growth in domestic demand. 
Even the difficult situation, there were also some positive developments. The depreciation of the zloty which intensified throughout 2002 had the effect of boosting exports growth in second half of the year, which resulted in the lowest current account deficit in many years. Exports increased by 10.4 per cent to USD $56777 \mathrm{mn}$, while imports increased by 8.4 per cent to USD $63177 \mathrm{mn}$. This resulted in a reduction in the deficit on the trade balance to USD $6400 \mathrm{mn}$, and a reduction in the deficit on the current account to USD $5007 \mathrm{mn}$.

The inflation target for 2002 was set to 5 per cent, with a permissible deviation of \pm 1 percentage point. This target constituted an element of the medium-term target, defined as bringing inflation down to below 4 per cent at the end of 2003. However the inflation rate this year was only 1.9 per cent. Some of the reasons for this low inflation were

- $\quad$ higher than forecasted supply on the agricultural market led to a decline in the prices of agricultural products, and consequently, to declining retail food prices

- $\quad$ increase in officially controlled prices was lower than expected

- $\quad$ growth recorded on the EU markets, of particularly high importance to Poland, given the scale of economic ties, proved much weaker than originally expected. In Germany, Poland's most important economic partner, the GDP grew by a mere 0.2 per cent, which was the lowest since 1993

As a result the year 2002 witnessed widespread reviews of economic forecasts in Poland and abroad. Forecasted economic growth and inflation rate were substantially reduced. As a result, in order to avoid a misleading interpretation as to the future direction of the monetary policy and to preserve its transparency, the Monetary Policy Council lowered the inflation target for 2002 to 3 per cent, with a permissible deviation band of \pm 1 percentage point in June 2002. In the course of the year, the MPC lowered NBP base rates on eight occasions.

Due to the slow economic growth the unemployment continued to rise, but at a slower rate than earlier. By 31.12.02 the number of unemployed was 3217000 people i.e. 18.1 per cent.

\subsection{The year 2003}

After two years with low economic growth, 2003 was a year with upward trends in the economy, with a growth in the GDP by 3.9 per cent. This was due to a significant increase in exports of goods and services.

Exports increased by 27 per cent to USD $72153 \mathrm{mn}$, despite unfavourable external conditions, with very low economic growth in the Euro zone, which is of special importance to Poland. The same year imports increased by more than 22 per cent to USD $77383 \mathrm{mn}$, which resulted in a deficit of the trade balance amounted to USD $5230 \mathrm{mn}$. The reduced deficit of the trade balance resulted in a reduced deficit on the current account, down to USD $4635 \mathrm{mn}$. This was the forth successive year with a falling current account deficit. As percentage of the GDP, the deficit has been reduced from 7.5 per cent to 2.2 per cent.

The long-term process of curbing inflation in Poland has resulted in limiting the inflation rate to levels recorded in developing countries in recent years. The interest rates were reduced six times in the first half of the year, and still the inflation rate was only 0.8 per cent; which was below the inflation target.

The biggest problem in the Polish economy is still the high number of unemployed persons, more than 3000000 people, and more than 50 per cent of the registered unemployed had been jobless for over a year. The Central Statistical Office has estimated that about 900000 people are employed in the grey economy, not paying taxes or social security contributions.

Another big problem in the Polish economy is the deficit of the State budget which in 2003 amounted to 4.5 per cent of the GDP, i.e. 0.5 per cent less than in 2002. The State public debt amounted to 51.6 per cent of the GDP at the end of this year.

Even with a relatively strong growth in the GDP there was only a small decrease in unemployment. By 31.12.03 the number of unemployed was 3176000 or 20.0 per cent, or down by only 41000 compared to 31.12.02. 


\subsection{The year 2004}

This year brought a continuation to the recovery in the Polish economy which had been started the previous year. The recovery coincided with a powerful demand stimulus related to Poland's accession to the European Union from May 1. The growth rate of the GDP stood at 5.3 per cent, which means that the Polish economy was developing more than two times faster than the EU 25 countries. The economic growth, however, was substantially faster in the first half of the year and slower in the second half. Even with the strong economic growth, the unemployment was reduced by only 176000 people to 3000000 , i.e. 19.0 per cent by the end of the year.

The inflation rate was 3.5 per cent, well above the inflation target at 2.5 per cent with a tolerance band for deviation of \pm 1 percentage point. The main reasons behind these figures are:

- $\quad$ increased demand from abroad as a result of Polish membership in the EU

- $\quad$ increased domestic demand at the beginning of the year as a result of expected price increases when Poland entered the EU from May 1

- $\quad$ increased value added taxes in accordance with the EU rules

- $\quad$ increased oil price in the world market

To curb the inflation the Monetary Policy Council increased the NBP interest rates in three consecutive months - in June, July and August.

For the fifth consecutive year an improvement in net exports was recorded, while the pace of the reduction of its deficit was markedly lower than in 2003. The deficit on the trade balance was reduced by USD 390mn to USD $4840 \mathrm{mn}$, while the current account deficit was reduced by almost one billion USD to USD $3637 \mathrm{mn}$.

\subsection{The year 2005}

This was the second year of Poland's membership in the European Union. The GDP increased by 3.6 per cent compared to 5.3 last year. The reduced growth rate can be traced to a reduction in the growth in the GDP for the euro area, from 2.1 per cent last year to 1.3 per cent this year, which accounts for 54 per cent of Polish export.

During the year the inflation rate decreased. This has to do with the fact that the membership of the EU and increased value added taxes in accordance with the EU rules only affected price increases the first quarter of 2005. Also the appreciation of the zloty exchange rate by 14 per cent against the euro and by 20 per cent against the USD contributing to lowering annual inflation.

During the period from February to August the NBP lowered the interest rate from 6.5 per cent to 4.5 per cent. This expansive monetary policy was one of the main factors behind the relative strong growth in the GDP.

According to data from the NBP the value of exports measured in euro increased by more than 17 per cent, while imports increased by almost 13 per cent. This was the fifth year in a row the deficit of the trade balance was reduced. The deficit was reduced from Euro 4.6 billion last year to Euro 2.2 billion this year. The deficit amounted to 0.9 per cent of the GDP compared to 2.2 per cent last year. The same figures for the current account deficit were 1.2 per cent and 4.0 per cent respectively.

Due to the relatively strong growth in the GDP the unemployment was reduced to 17.6 per cent or 2773000 by the end of the year.

\subsection{The year 2006}

Compared to previous year the GDP increased by 6.2 per cent. This was due to a strong growth in investment demand and in private consumption due to faster growth of disposable income than in the previous year. It has also to do with strong growth in the economies of Poland's main trading partners, resulting in a significant increase in Polish exports. 
The NBP reduced the main interest rate two times at the beginning of the year, from 4.5 per cent to 4.0 per cent, but the inflation rate was only 1.0 per cent, i.e. well below the inflation target. This had to do with imports from low-cost production countries.

Exports and imports hit the highest level this century due to acceleration in the demand both in Poland and abroad. For the first time since 1999 (except 2004) the growth rate of import, exceeded the growth rate of export. This has to do with deepening of the trade balance with Russia and China.

Increased deficit in the trade balance widened the current account balance deficit from Euro 2.1 billion last year to Euro 7.3 billion this year.

The strong economic growth led to a decrease in unemployment by 464000 , and the unemployment rate went down from 17.6 per cent to 14.9 per cent.

\subsection{The year 2007}

The growth in the GDP this year at 6.8 per cent was the strongest growth of the last ten years.

Huge increase in the demand for labour and also emigration of Polish workers to EU countries resulted in an acceleration in wages and labour unit costs, and also in the inflation rate during the year. The inflation rate also increased as a result of diminishing agricultural output in many regions, increased demand from developing countries, and growth in the bio-fuel market supported by governments in the developed countries. On the other hand the inflation rate was curbed by the decline in the prices of goods imported from countries with low production costs and also as a result of the appreciation of the zloty against the euro and the USD.

By the end of the year the inflation rate reached the upper level of the inflation target, i.e. 3.5 per cent, while the average increase in the consumer prices was in line with the inflation target at 2.5 per cent. As a result of the tendency of increased inflation during the year the NBP increased the interest rate four times from 4.0 per cent to 5.0 per cent.

Due to very strong growth in the GDP imports increased more than exports - 15 per cent and almost 18 per cent respectively - which resulted in a further deterioration of the current account. This year the deficit was Euro 11.5 billion or 4.7 per cent of the GDP compared to 2.7 per cent last year.

Like last year, strong economic growth lead to a reduction in the number of unemployed, this year by 562000 compared to last year, and the unemployment rate went down from 14.9 per cent to 11.4 per cent.

\subsection{The year 2008}

Like the previous years, the strong economic growth in the first part of this year was driven by a strong increase both in private consumption and private investments.

The global financial crisis starting in the second half of 2008 imposed a significant drop in the property prices and the assets prices, and resulted in reduced consumption and GDP in the USA and then in the world market, resulting in the worst crisis in the world economy since the Second World War. At the same time Poland experienced a drop in the growth rate, but the GDP still grew by 5.0 per cent compared to last year.

Strong economic growth and an increased inflation rate during the first two quarters resulted in an increased interest rate at four occasions by the Monetary Policy Council. In the last quarter, however, the interest rate was reduced twice, and was back at the same level as in the beginning of the year, at 4.0 per cent.

The inflation rate in 2008 was 4.2 per cent, well above the inflation target. This was a result of a significant inflation on the world market, mainly because of a price surge in the global agricultural and energy commodity markets in the first half of the year. 
As a whole the value of exports rose by 12.5 per cent; the slowest growth rate since Poland joined the EU in 2004. The imports rose by almost 16 per cent resulting in an increased deficit for the third consecutive year. There was a deepening in the trade deficit with China and Russia, while the trade surplus with the European Union was almost the same as last year. The current account deficit increased from 4.7 per cent last year to 5.1 per cent of the GDP this year.

Due to strong economic growth most of the year, the number of unemployed by the end of the year was 1474000 or 9.5 per cent. This is the lowest level since the introduction of the new economic system in 1990 .

\subsection{The year 2009}

Due to the crisis in the financial markets starting in the second half of last year rich countries experienced substantial decrease in the GDP throughout 2009. However, as the only country in the EU Poland's GDP increased also this year. The reduced growth rate from 5.0 per cent to 1.7 percent was a result of reduced investments and reduced growth rate in private consumption. Reduced growth in private consumption was a result of both increased households savings and a unfavourable situation in the labour market. By the end of this year the number of unemployed was 1893000 or 11.9 per cent of the labour force.

The huge problems and uncertainty in the world economy resulted in a reduction in the interest rate by the NBP on four occasions in the first half of 2009. Additionally the NBP lowered the banks required reserve ratio from 3.5 per cent to 3.0 per cent as part of an expansive monetary policy. As a whole the CPI increased on average by 3.5 per cent, i.e. in the upper limit of the inflation target.

Due to negative economic growth in the world economy this year, the volume of global trade fell by 13 per cent. The value of Polish exports decreased by more than 17 per cent, while the value of imports contracted by more than 26 per cent in the same period. This was connected with the depreciation of the zloty exchange rate in the end of 2008 and in the beginning of 2009. The deficit on the trade balance went down from EUR 26.2 billion in 2008 to EUR 8.7 billion this year. In the same period the deficit on the current account went down from EUR 18.3 billion to EUR 5.0 billion, i.e. from 5.1 per cent to only 1.6 per cent of the GDP.

\section{CONCLUDING REMARKS}

The transformation of the Polish economy to a market economy from January 1, 1990 led to a deeper recession than expected during the two first years of the transformation process. The GDP decreased by 18.3 per cent from an already low level. In the same period the level of unemployment reached more than 2000000 people or 11.8 per cent and the consumer prices increased by almost 1070 per cent.

During the period 1990-2009 the average annual growth rate in the GDP and the private consumption were 2.9 per cent and 3.3 per cent respectively. If we look at the period 1992-2009; after the big recession due to the adoption of the new economic system, the GDP and the private consumption show an average annual growth rate of 4.4 per cent and 4.2 per cent respectively.

Still twenty years after the beginning of the transformation process the standard of living is far behind most OECD countries. With an average annual growth rate in the GDP of 3.5 per cent the next twenty years, the standard of living will be around the average level of the OECD countries today.

Preliminary figures from the Central Bureau of Statistics show that the GDP increased by 3.8 per cent in 2010, and the OECD expects the GDP to increase by 4.0 in 2011 and 4.3 per cent in 2012.

As a whole the implemented policy enabled Poland to transform its economy into one of the most robust ones in Central and Eastern Europe. 
Table 1. Growth in the GDP measured in fixed prices - percentage change from previous year

\begin{tabular}{|c|c|}
\hline Year & Percentage change \\
\hline 1990 & -11.6 \\
\hline 1991 & -7.6 \\
\hline 1992 & 1.5 \\
\hline 1993 & 3.8 \\
\hline 1994 & 5.2 \\
\hline 1995 & 7.0 \\
\hline 1996 & 6.0 \\
\hline 1997 & 7.1 \\
\hline 1998 & 5.0 \\
\hline 1999 & 4.5 \\
\hline 2000 & 4.2 \\
\hline 2001 & 1.1 \\
\hline 2002 & 1.4 \\
\hline 2003 & 3.9 \\
\hline 2004 & 5.3 \\
\hline 2005 & 3.6 \\
\hline 2006 & 6.2 \\
\hline 2007 & 6.8 \\
\hline 2008 & 5.0 \\
\hline 2009 & 1.7 \\
\hline
\end{tabular}

Source: Central Statistical Office

Table 2. Price indices of consumer goods and services (CPI) - percentage change from previous year

\begin{tabular}{|c|c|}
\hline Year & Percentage change \\
\hline 1990 & 585.8 \\
\hline 1991 & 70.3 \\
\hline 1992 & 43.0 \\
\hline 1993 & 35.3 \\
\hline 1994 & 32.2 \\
\hline 1995 & 27.8 \\
\hline 1996 & 19.9 \\
\hline 1997 & 14.9 \\
\hline 1998 & 11.8 \\
\hline 1999 & 7.3 \\
\hline 2000 & 10.1 \\
\hline 2001 & 5.5 \\
\hline 2002 & 1.9 \\
\hline 2003 & 0.8 \\
\hline 2004 & 3.5 \\
\hline 2005 & 2.2 \\
\hline 2006 & 1.0 \\
\hline 2007 & 2.5 \\
\hline 2008 & 4.2 \\
\hline 2009 & 3.5 \\
\hline
\end{tabular}

Source: Central Statistical Office 
Table 3. Unemployment per 31.12 each year*

\begin{tabular}{|c|c|c|}
\hline Year & Number of unemployed & Unemployment rate \\
\hline 1990 & 1126000 & 11.8 \\
\hline 1991 & 2155000 & 13.6 \\
\hline 1992 & 2509000 & 15.7 \\
\hline 1993 & 2890000 & 14.9 \\
\hline 1994 & 2838000 & 13.6 \\
\hline 1995 & 2629000 & 10.3 \\
\hline 1996 & 2360000 & 10.4 \\
\hline 1997 & 1826000 & 13.0 \\
\hline 1998 & 1831000 & 15.1 \\
\hline 1999 & 2350000 & 17.5 \\
\hline 2000 & 2703000 & 18.1 \\
\hline 2001 & 3115000 & 20.0 \\
\hline 2002 & 3217000 & 19.0 \\
\hline 2003 & 3176000 & 17.6 \\
\hline 2004 & 3000000 & 14.8 \\
\hline 2005 & 2773000 & 11.4 \\
\hline 2006 & 2309000 & 9.5 \\
\hline 2007 & 1747000 & 11.9 \\
\hline 2008 & 1474000 & \\
\hline
\end{tabular}

*) From 2003 the unemployment is estimated differently from this of previous years

Source: Central Statistical Office

Table 4. GDP per capita in US dollars (current PPP's) - 2008; OECD - countries

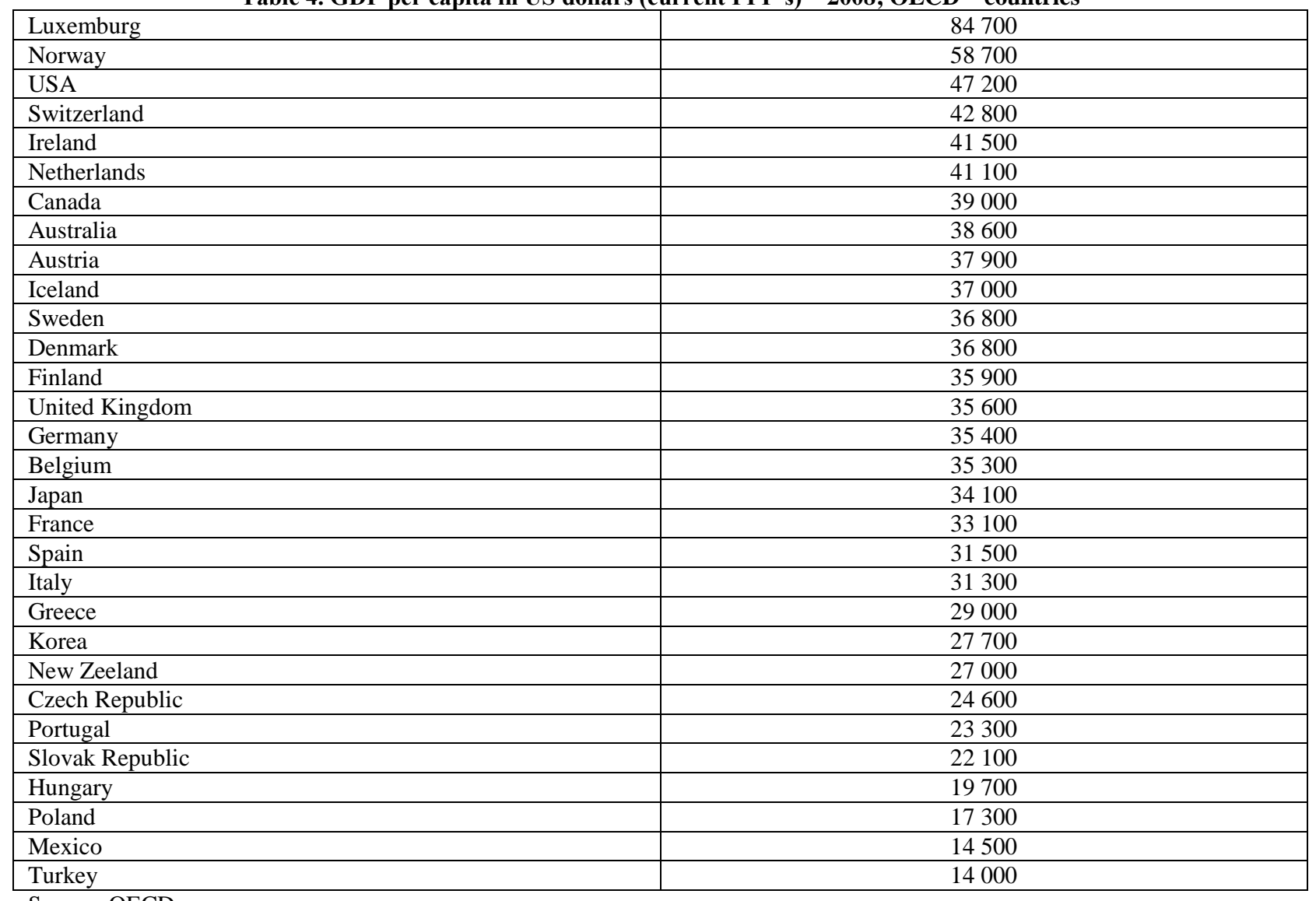

Source: OECD 


\section{ACKNOWLEDGMENT}

A lot of information for this article was taken from the Annual Report from 1990 to 2009 published by the National Bank of Poland

\section{AUTHOR INFORMATION}

Gorm Jacobsen has bachleor degree in business administration from University of Lund in Sweden (1977), and master degree in economics from University of Oslo in Norway (1986). Currently has position of Associate Professor of economics at Department of Working life and Innovation, Faculty of Economics and Social Sciences at University of Agder in Norway. E-mail: gorm.jacobsen@uia.no

\section{REFERENCES}

1. Annual Report 1990 - 2009: National Bank of Poland

2. OECD Fact book 2010: Economic, Environmental and Social Statistics

3. OECD - Poland - Economic Outlook 88 Country Summary (2010) 